\title{
Gamma interferon: from antimicrobial activity to immune regulation
}

\author{
Howard M. Johnson* \\ Microbiology and Cell Science, University of Florida, Gainesville, FL, USA \\ *Correspondence: johnsonh@ufl.edu \\ Edited and reviewed by: \\ Kendall A. Smith, Weill Medical College of Cornell University, USA
}

Keywords: interferon, antiviral, SOCS, JAK/STAT pathway, pathogens, cell signaling

Gamma interferon (IFN $\gamma$ ) was discovered in 1965 as an antiviral activity in white blood cell cultures stimulated with the lymphocyte mitogen phytohemagglutinin (1). At that time, IFN $\gamma$, as was the case with the much earlier discovered type I IFNs, was thought to strictly function as an antiviral. It was noted, however, that IFN $\gamma$ was more sensitive than type I IFNs to extremes of $\mathrm{pH}$ and temperatures of $56^{\circ} \mathrm{C}$ or higher, a suggestion that it was a different kind of IFN.

We played a key role in the first demonstration that IFN $\gamma$ along with the type I IFNs regulated immune functions (24). These discoveries were confirmed and extended by others, making IFNs the first well-characterized cytokines. The reviews presented here provide important insight into our current understanding of the structural basis of the mechanism of specific gene activation by IFN $\gamma$, how its activity is regulated by immune modulators called suppressors of cytokine signaling (SOCS) and regulatory $\mathrm{T}$ cells, its effector role in autoimmunity, and how it functions as a key factor in host defense against viral and parasitic diseases.

The first three articles deal, respectively, with a non-canonical model of IFN $\gamma$ signaling (5), the role of IFN $\gamma$ receptor in such signaling (6), as well as epigenetic aspects of activation of the IFN $\gamma$ gene (7). SOCS and regulatory $\mathrm{T}$ cells (Tregs) play the key role as governors of signaling by cytokines such as IFN $\gamma$. Too much regulation can be detrimental in immune regulation of diseases such as cancer while too little can result in autoimmune disease. Thus, the fourth article addresses cross-talk between SOCS1 and Tregs in the context of regulation of IFN $\gamma$ (8). The cross-talk between the systems is a novel observation with SOCS1 playing the hierarchical role.

With respect to viral diseases, IFN $\gamma$ is discussed in the context of human immunodeficiency virus-1 (HIV-1) (9) and herpes simplex virus-1 (HSV-1) (10). These are difficult viruses to control in an infectious setting. HSV-1 attacks the immune system as well as the central nervous system (CNS). The HIV-1 review points out the complex relationship between IFN $\gamma$ and this virus where both therapeutic as well as exacerbative effects on HIV-1 pathogenesis have been attributed to IFN $\gamma$. HSV-1 is a difficult, persistent neurotropic infectious virus. The relationship of IFN $\gamma$ to HSV-1 pathogenesis is defined more clearly than is the case for HIV-1. For example, IFN $\gamma$ plays a key role in preventing the virus from exiting the latency state.

IFN $\gamma$ is a key player in regulation of protective immunity against blood-stage malaria, and this is discussed in the context of gamma/delta T cells (11). Specifically, certain gamma/delta $\mathrm{T}$ cells produce IFN $\gamma$ after Plasmodium infection, which is shown to be involved in dendritic cell reduction of Plasmodium parasites in the blood. IFN $\gamma$ is probably the key cytokine in host defense against Leishmania infections in general although different Leishmania species may respond differently against this cytokine (12). Even so, IFN $\gamma$ appears to function cooperatively with chemokines such as CXCL10 in $\mathrm{CD}^{+} \mathrm{T}$ cell response to Leishmania-infected cells.

Finally, IFN $\gamma$ as well as type I IFNs may function cooperatively in promotion of Sjogren's syndrome as shown by upregulation of IFN response genes (IRGs) (13). Sjogren's syndrome is characterized by chronic immune attacks against exocrine glands (such as salivary glands) leading to exocrine dysfunction. An SOCS1 mimetic plays an important role in inhibiting the inflammatory aspect of autoimmune diseases such as multiple sclerosis as pointed out in the fourth review (8). Thus, given the importance of the IFNs in Sjogren's syndrome, it would seem that it would be a candidate for potential SOCS1 mimetic therapy based on the experience with other autoimmune diseases. The SOCS and Sjogren's syndrome reviews as well as others presented here, therefore, are interrelated in terms of approaches to dealing with diseases where IFN $\gamma$ may play either a positive or negative role.

\section{REFERENCES}

1. Wheelock EF. Interferon-like virus-inhibitor induced in human leukocytes by phytohemagglutinin. Science (1965) 149:310-1. doi:10.1126/science.149. 3681.310

2. Johnson HM, Stanton GJ, Baron S. Relative ability of mitogens to stimulate production of interferon by lymphoid cells and to induce suppression of the in vitro immune response. Proc Soc Exp Biol Med (1977) 154(1):138-41. doi:10.3181/00379727-154-39622

3. Osborne LC, Georgiades JA, Johnson HM. Classification of interferons with antibody to immune interferon. Cell Immunol (1980) 53:65-70. doi:10.1016/ 0008-8749(80)90426-8

4. Langford MP, Weigent DA, Georgiades JA, Johnson HM, Stanton GJ. Antibody to staphylococcal enterotoxin A-induced human immune interferon (IFN $\gamma$ ). J Immunol (1981) 126(4):1620-3.

5. Johnson HM, Noon-Song EN, Dabelic R, Ahmed CM. IFN signaling: how a non-canonical model led to the development of IFN mimetics. Front Immunol (2013) 4:202. doi:10.3389/fimmu.2013.00202

6. Lamaze C, Blouin CM. Interferon gamma receptor: the beginning of the journey. Front Immunol (2013) 4:267. doi:10.3389/fimmu.2013.00267

7. Aune TM, Collins PL, Collier SP, Henderson MA, Chang S. Epigenetic activation and silencing of the gene that encodes IFN- $\gamma$. Front Immunol (2013) 4:112. doi:10.3389/fimmu.2013.00112 
8. Larkin J, Ahmed CM, Wilson TD, Johnson HM. Regulation of interferon gamma signaling by suppressors of cytokine signaling and regulatory $\mathrm{T}$ cells. Front Immunol (2013) 4:469. doi:10.3389/fimmu.2013.00469

9. Yamamoto JK, Roff SR, Noon-Song EN. The significance of interferon- $\gamma$ in HIV-1 pathogenesis, therapy, and prophylaxis. Front Immunol (2014) 4:498. doi:10.3389/fimmu.2013.00498

10. Bigley NJ. Complexity of interferon- $\gamma$ interactions with HSV-1. Front Immunol (2014) 5:15. doi:10.3389/fimmu.2014.00015

11. Inoue S, Nikura M, Mineo S, Kobayashi F. Roles of IFN- $\gamma$ and $\gamma 8 \mathrm{~T}$ cells in protective immunity against blood-stage malaria. Front Immunol (2013) 4:258. doi:10.3389/fimmu.2013.00258

12. Kima PE, Soong L. Interferon gamma in leishmaniasis. Front Immunol (2013) 4:156. doi:10.3389/fimmu.2013.00156

13. Nguyen CQ, Peck AB. The interferon-signature of Sjogren's syndrome: how unique biomarkers can identify underlying inflammatory and immunopathological mechanisms of specific diseases. Front Immunol (2013) 4:142. doi:10. 3389/fimmu.2013.00142
Conflict of Interest Statement: The author declares that the research was conducted in the absence of any commercial or financial relationships that could be construed as a potential conflict of interest.

Received: 03 November 2014; accepted: 11 December 2014; published online: 05 January 2015.

Citation: Johnson HM (2015) Gamma interferon: from antimicrobial activity to immune regulation. Front. Immunol. 5:667. doi: 10.3389/fimmu.2014.00667

This article was submitted to Immunotherapies and Vaccines, a section of the journal Frontiers in Immunology.

Copyright $(\odot) 2015$ Johnson. This is an open-access article distributed under the terms of the Creative Commons Attribution License (CC BY). The use, distribution or reproduction in other forums is permitted, provided the original author(s) or licensor are credited and that the original publication in this journal is cited, in accordance with accepted academic practice. No use, distribution or reproduction is permitted which does not comply with these terms. 